\section{Temperature and Relative Humidity Govern Germination and Storage of Gladiolus Seed}

\author{
W.J. Carpenter ${ }^{1}$ \\ Environmental Horticulture Department, Institute of Food and \\ Agricultural Sciences, University of Florida, Gainesville, FL 32611
}

\section{G.J. Wilfret ${ }^{1}$}

University of Florida, Gulf Coast Research and Education Center, 5007

60th St., E. Bradenton, FL 34203

\author{
J.A. Cornell \\ Department of Statistics, Institute of Food and Agricultural Sciences, \\ University of Florida, Gainesville, FL 32611
}

Additional index words. Gladiolus grandiflorus, seed moisture content, storage temperatures, statistical models

\begin{abstract}
Gladiolus (G. grandiflorus) seed germination was light-independent, but temperature influenced the germination rate. Constant $20 \mathrm{C}$ promoted higher total germination $(97 \%)$, fewer days $(4.3)$ to $50 \%$ of final germination, and shorter span of days $(4.8)$ between $10 \%$ and $90 \%$ germination than other constant temperatures, although similar results were achieved by alternating 12-h cycles of 20 to $25 \mathrm{C}$. Total germination was unchanged after seed treatment for 7 days at 10 to $-20 \mathrm{C}$, but longer germination periods were required after treatments below -10C. Reducing seed moisture contents from $11.8 \%$ to $4.2 \%$ caused no reduction in total germination, but moisture contents below $6.6 \%$ delayed achieving $50 \%$ of final germination and extended the periods from $10 \%$ to $90 \%$ of germination. Temperature and relative humidity (RH) during storage were important in retaining seed viability, with RH having a larger effect. Smallest declines in total germination during 12 months of storage occurred at $11 \%$ and $33 \% \mathrm{RH}$ at $15 \mathrm{C}$. The statistical analysis estimated the optimum seed storage at $14 \mathrm{C}$ and $26 \%$ RH.
\end{abstract}

Optimum seed storage and germination of gladiolus are important to gladiolus hybridizers. Since seeds are harvested in the early fall and not planted until the following spring, they are stored for 6 to 7 months at 5 to $15 \mathrm{C}$ (Griesbach, 1972). Kelly (1953) reported seeds will survive short storage periods below $0 \mathrm{C}$ if harvested when mature and dried before storage. At $20 \mathrm{C}, 14$ to 21 days are required to germinate $50 \%$ to $70 \%$ of the seeds (Pickell, 1972). Freshly harvested gladiolus seeds are enclosed in a waxy, oily wing that can delay germination (Griesbach, 1972); therefore, most seeds are "dewinged" before planting. The seed of many of the late-flowering species, e.g., $G$. maculatus 'Sweet', can be germinated only after 6 months of storage (Lewis et al., 1972). Of the 180 species of gladiolus, almost $90 \%$ are endemic to southern Africa and many are very rare or endangered (Lewis et al., 1972). Only seed may be exported to permit hybridization with other species. Leaves, flowers,

Received for publication 24 Oct. 1990. Florida Agricultural Experiment Station Journal Series no. R-01104. The cost of publishing this paper was defrayed in part by the payment of page charges. Under postal regulations, this paper therefore must be hereby marked advertisement solely to indicate this fact.

'Professor of Environmental Horticulture.

${ }^{2}$ Professor of Statistics. and corms may be infected with gladiolus smut (Urocystis gladiolicola Ainow), which prohibits their entry into Europe and North America (Magie and Poe, 1972). The development of long-term seed storage recommendations is important for the preservation of this genus. Objectives of this research were to determine the optimum environmental conditions for the storage and germination of gladiolus seeds.

Light and temperature studies. Gladiolus seeds from controlled self-crosses among inbred lines of cv. Dr. Magie were obtained from a breeding program. Seeds were harvested 5 weeks after pollination and prepared by removing the winged appendages and dusting with 3a,4,7,7a-tetrahydro-2-[(trichloromethyl)thiol]-W-isoindole-1,3(2H)-dione (captan) before germination. In all experiments, there were four blocks with 100 -seed replicates for each treatment. The seeds of each replicate were germinated in a 9-cm petri dish on a moistened with $5 \mathrm{ml}$ of distilled water (dw). Imbibed seeds were kept in darkness or in continuous incandescent light, 50 $\mu \mathrm{mol} \cdot \mathrm{s}^{-1} \cdot \mathrm{m}^{-2}$ of photosynthetically active radiation (PAR), in incubators at a constant $10,15,20,25,30$, or $35 \pm 1 C$. Daily germination counts were made of seeds with visible radicle protrusion through the testa. Total absolute germination percent $(\mathrm{G})$, days to $50 \%$ of final germination $\left(\mathrm{T}_{\mathrm{so}}\right)$, and gerdouble layer of Whatman no. 1 filter paper mination span measured in number of days between $10 \%$ and $90 \%$ germination $\left(\mathrm{T}_{90}\right.$ $\mathrm{T}_{10}$ ), were calculated as recommended by Furutani et al. (1985). We used a randomized complete block design arranged as a $2 \times 6$ factorial, with data tested by analysis of variance (ANOVA). Polynomial equations relating $G, T_{50}$, and $T_{90}-T_{10}$ to temperature were fitted using SAS (1982).

In a second study, treatments with four blocks of 100-seed replicates were established following cleaning and seed storage of 14 days at $5 \mathrm{C}$ and $45 \%$ RH. Seeds were germinated in dark incubators at alternating temperatures (12-h) regimes of 15 to $20 \mathrm{C}$, 15 to $25 \mathrm{C}, 15$ to $30 \mathrm{C}, 15$ to $35 \mathrm{C}, 20$ to $25 \mathrm{C}$, 20 to $30 \mathrm{C}, 20$ to $35 \mathrm{C}, 25$ to $30 \mathrm{C}$, or 25 to 35C. The $G, T 50$, and $T_{90}-T_{10}$ were calculated from the daily germination counts and data were analyzed by Tukey's honestly significant difference test at $P=0.05$.

Seed moisture content. After the preparation of freshly harvested seeds, 100-seed lots were weighed, placed in open $9-\mathrm{cm}$ petri dishes, and dehydrated in forced-draft ovens at $40 \mathrm{C}$ for $0,8,16,24,48,72,96$, or 120 h. Following cooling after dehydration, seeds were reweighed and immediately placed in 5-ml sealed glass vials, held for 7 days, then germinated in darkness at 20C. Daily germination counts were recorded, $\mathrm{G}, \mathrm{T}_{\mathrm{so}}$, and $\mathrm{T}_{90}-\mathrm{T}_{10}$ calculated, and data analyzed by the least significant difference test (LSD) at $P=0.05$. After cleaning, four lots of 100 seeds were weighed, dehydrated in a forceddraft oven at $105 \mathrm{C}$ for $48 \mathrm{~h}$, and reweighed after cooling to determine the seed initial moisture content.

Storage temperature. After seed preparation, moisture contents were reduced by placing seeds in $15 \times 2.5-\mathrm{cm}$ petri dishes on wire screens supported by segments of tubing $1 \mathrm{~cm}$ above a chemical desiccant. Constant $22 \% \mathrm{RH}$ was maintained in the sealed petri dishes by adding $50 \mathrm{ml}$ of saturated potassium acetate to the bottom of each dish (Copeland, 1976). The refrigerated incubators maintained $15 \mathrm{C}$ during 1 week of seed dehydration. Seeds were placed immediately in 10-ml glass vials, that were sealed and immersed in polyethylene glycolwater $(\mathrm{v} / \mathrm{v})$ in controlled-temperature baths

Table 1. Germination of gladiolus 'Dr. Magie' seed under alternating temperatures.

\begin{tabular}{lrrr}
\hline \hline \multirow{2}{*}{$\begin{array}{l}\text { Temperature } \\
\text { cycle }\end{array}$} & \multicolumn{3}{c}{ Germination } \\
\cline { 2 - 4 }$\left.{ }^{\circ} \mathrm{C}\right)$ & $\mathrm{G}^{y}$ & $\mathrm{~T}_{50}{ }^{\mathrm{x}}$ & $\mathrm{T}_{90}-\mathrm{T}_{10}{ }^{\mathrm{w}}$ \\
\hline $15-20$ & 48 & 7.1 & 7.3 \\
$15-25$ & 81 & 5.4 & 5.6 \\
$15-30$ & 57 & 22.2 & 11.4 \\
$15-35$ & 27 & 27.8 & 30.9 \\
$20-25$ & 96 & 4.0 & 4.6 \\
$20-30$ & 85 & 6.9 & 7.9 \\
$20-35$ & 51 & 11.3 & 11.7 \\
$25-30$ & 96 & 7.9 & 9.8 \\
$25-35$ & 22 & 13.9 & 14.4 \\
Tukey's HSD, 5\% & 7 & 2.6 & 3.4 \\
\hline
\end{tabular}

zTemperature alternated every $12 \mathrm{~h}$.

yPercent absolute final germination after 38 days. 'Days to $50 \%$ relative germination.

wDays from $10 \%$ to $90 \%$ relative germination. 


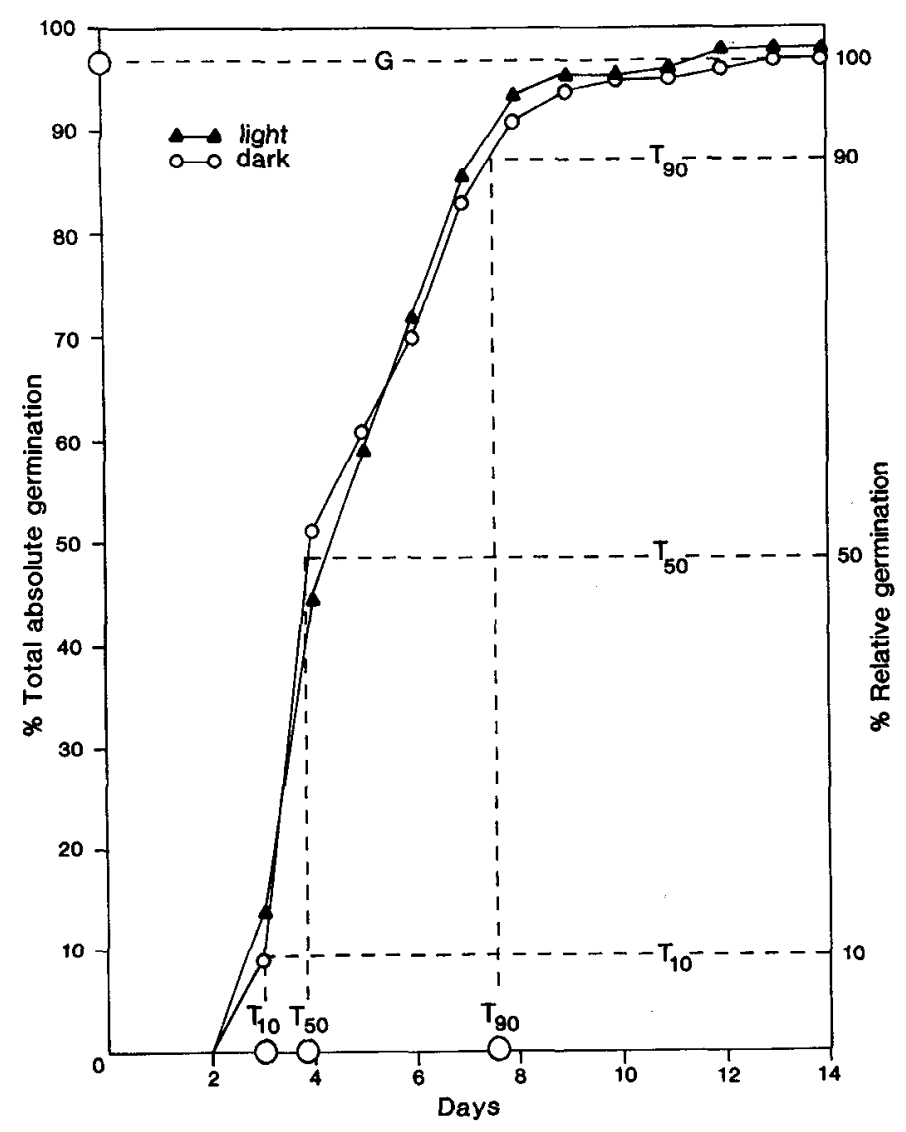

Fig. 1. Germination curves for gladiolus 'Dr. Magie' seed exposed to light or darkness at 20C, illustrating total absolute germination $(\mathrm{G})$, days to $50 \%$ relative germination $\left(\mathrm{T}_{50}\right)$, and germination span in days between $10 \%$ and $90 \%$ relative germination $\left(\mathrm{T}_{90}-\mathrm{T}_{10}\right)$.

(Guy and Carter, 1984) at 10, 5, 0, -5, $-10,-15$, or $-20 \mathrm{C}$. Bath temperatures were lowered $3 \mathrm{C} / \mathrm{h}$ to final temperatures, held for 7 days, then increased $4 \mathrm{C} / \mathrm{h}$ to $10 \mathrm{C}$. Following temperature treatments, seeds were germinated in dark 20C incubators. Daily germination counts were made, $\mathrm{G}, \mathrm{T}_{\mathrm{s}}$, and $\mathrm{T}_{90}-\mathrm{T}_{10}$ calculated, and data analyzed using LSD at $P=0.05$

Temperature and relative humidity interaction during seed storage. Freshly har- vested seeds were prepared as described previously, dusted with captan, and placed in storage at $11 \%, 33 \%, 52 \%, 75 \%$, or $95 \%$ $\mathrm{RH}$ and 5,15 , or $25 \mathrm{C}$ for $3,6,9$, or 12 months. Humidity treatments were achieved in $15 \times 2.5-\mathrm{cm}$ petri dishes as described previously, except different desiccants were used. Incubators with refrigeration and heating capacities maintained constant temperatures during seed storage. Seeds were germinated in darkness at 20C immediately after storage. The design was a randomized complete block arranged as a $5 \times 3 \times 4$ factorial. The data were analyzed by ANOVA, and transformed values using the $\arcsin \sqrt{\% \mathrm{G}}$ transformation were fitted by regression to produce plots of the arcsin $\sqrt{\% \mathrm{G}}$ surface for combinations of relative humidity, temperature, and storage duration.

Imbibed seeds receiving light or held in darkness had similar $\mathrm{G}, \mathrm{T}_{50}$, and $\mathrm{T}_{90}-\mathrm{T}_{10}$ values (Fig. 1). No light $\times$ temperature indicators were found; therefore, data for light and dark treatments were combined for analysis in Fig. 2. Temperature influenced seed germination, with $20 \mathrm{C}$ promoting the highest $\mathrm{G}$ (Fig. 2A). The germination percentage curve, expressed as a function of temperature, was cubic (Fig. 2A). Days to $\mathrm{T}_{\mathrm{so}}$ were similar for germination temperatures of $15,20,25$, or $30 \mathrm{C}$, but were greatly increased at 10 and 35C (Fig. 2B). The best fitting curve for days to $50 \%$ germination was cubic (Fig. 2B). The shortest span between $\mathrm{T}_{90}-\mathrm{T}_{10}$ occurred at $20 \mathrm{C}$ with progressively longer periods as temperatures increased above or declined below 20C. The trend curve for $\mathrm{T}_{90}-\mathrm{T}_{10}$ was quadratic (Fig. 2C).

Highest total germination percentages were at 20 to $25 \mathrm{C}$ or 25 to $30 \mathrm{C}$ for seeds receiving alternating temperatures at 12 -h intervals (Table 1). Seeds given 12-h diurnal periods having one temperature at 15 or $35 \mathrm{C}$ had reduced G. Similar $\mathrm{G}$ values resulted from constant 20C (Fig. 2A) or alternating 20 to $25 \mathrm{C}$ or 25 to $30 \mathrm{C}$ (Table 1). Shortest $\mathrm{T}_{50}$ and $\mathrm{T}_{90}-\mathrm{T}_{10}$ occurred at 15 to $20 \mathrm{C}, 15$ to $25 \mathrm{C}$, or 20 to $25 \mathrm{C}$ (Table 1), with periods similar to those at constant 20C (Fig. $2 \mathrm{~B}, \mathrm{C}$ ). Alternating temperature combinations of 20 or $25 \mathrm{C}$ with $35 \mathrm{C}$ caused large delays in achieving $T_{50}$ and longer periods for $T_{90}-T_{10}$ (Table 1). Bewley and Black (1986) reported that temperature controls the rate of enzyme reactions and protein denaturation during seed germination, causing excessively high temperatures to be deleterious to germination. This offers a plausible explanation for the
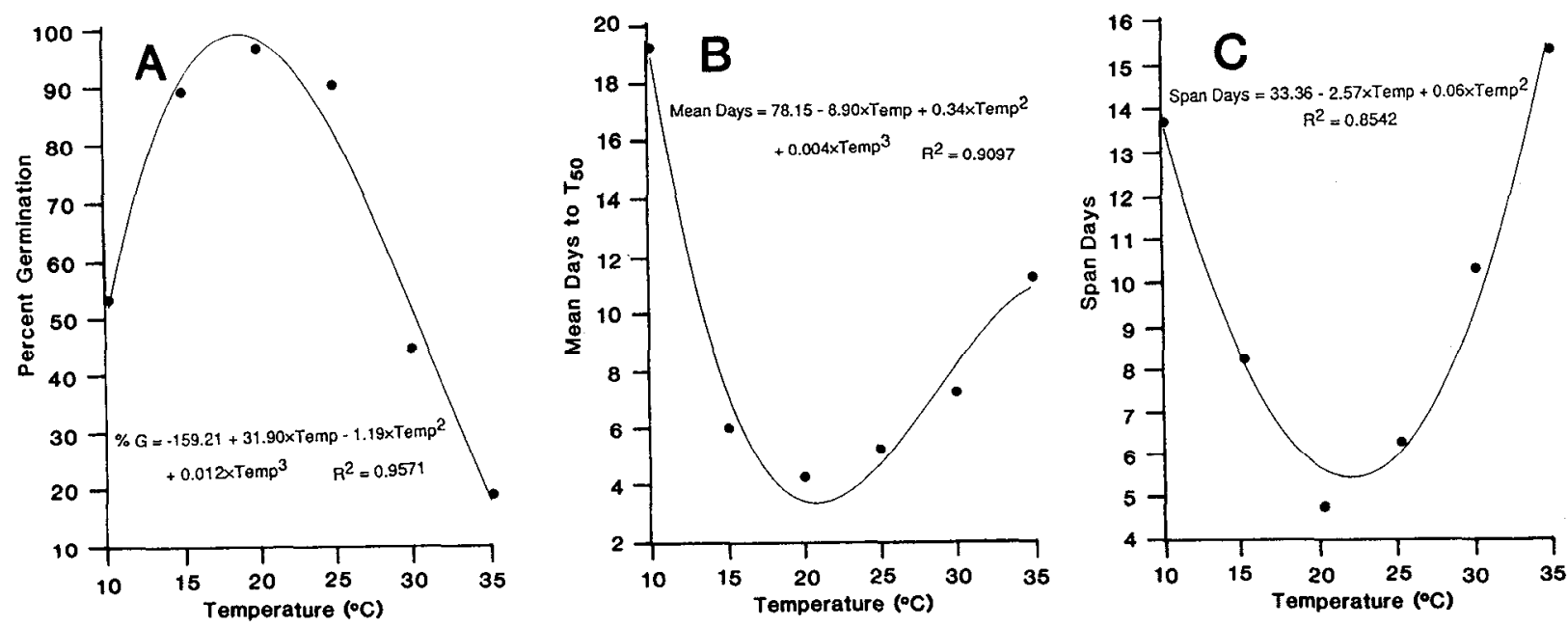

Fig. 2. Effect of temperature on gladiolus 'Dr. Magie' seed germination, from combined data for treatments in light and darkness, using polynomial equations relating (A) percent total germination, $(\mathrm{B})$ mean days to $50 \%$ germination $\left(\mathrm{T}_{50}\right)$, and $(\mathrm{C})$ germination span $\left(\mathrm{T}_{90}-\mathrm{T}_{10}\right)$ days to temperature, as fitted using SAS (1985). 


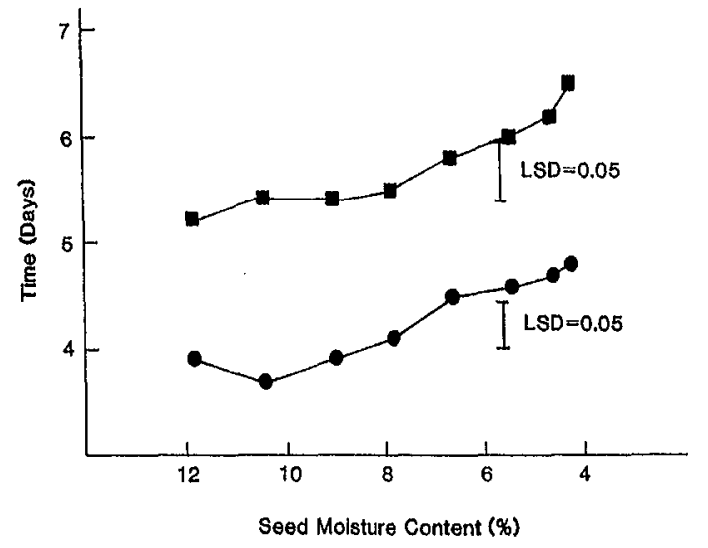

Fig. 3. Comparisons of gladiolus seed germination $\mathrm{T}_{50}$ reducing seed moisture contents for 7 days.

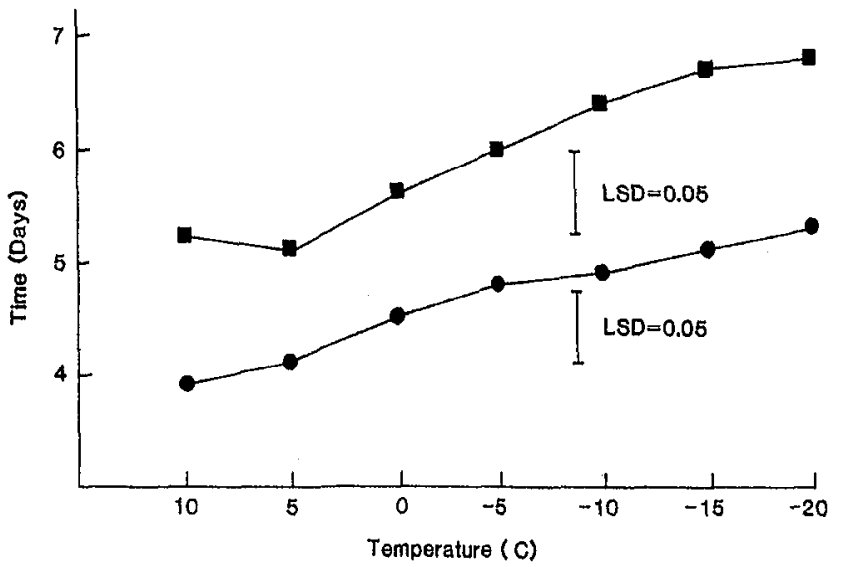

Fig. 4. Germination of gladiolus seed in darkness after low temperature seed storage for 7 days, comparing treatment $\mathrm{T}_{50}(\boldsymbol{O})$, and $\mathrm{T}_{90}-\mathrm{T}_{10}(\mathbf{\square})$. low $\mathrm{G}$ and delayed germination at constant or alternating $35 \mathrm{C}$.

Gladiolus seeds were tolerant of extensive desiccation, with similar $\mathrm{G}$ values at all seed moisture contents from $11.8 \%$ to $4.2 \%$ (data not presented). Reducing seed moisture from $11.8 \%$ to $7.8 \%$ left $\mathrm{T}_{50}$ and $\mathrm{T}_{90}-\mathrm{T}_{10} \mathrm{un}-$ changed, but lower levels caused significant delays in germination (Fig. 3). Seeds having $4.2 \%$ to $6.6 \%$ moisture were found to require longer periods for seed rehydration. Seeds were more tolerant of desiccation than Pridham and Thompson (1930) found for gladiolus corms.

Seeds were cold-tolerant, and $\mathrm{G}$ values of seeds held at 10 to - 20C were similar (data not presented). Both $\mathrm{T}_{50}$ and $\mathrm{T}_{90}-\mathrm{T}_{10}$ were unchanged when seeds with $9.6 \%$ moisture content were stored at 10 to $-5 \mathrm{C}$ for 7 days, but -10 to $-20 \mathrm{C}$ lengthened the periods of germination (Fig. 4). Seeds were more coldtolerant than gladiolus corms during storage (Emsweller, 1930). Pridham (1930) found that corms were severely injured or killed during storage below -1C. Emsweller (1930) reported the successful storage of corms between $3.5 \mathrm{C}$ and $30 \mathrm{C}$, with earlier and fewer days to flowering from corms stored at 30C.

The three-dimensional plot and contour plot (Fig. 5 A, B) from the statistical analysis predicted that optimal seed storage occurs at $14 \mathrm{C}$ with $26 \% \mathrm{RH}$, as based on the maximum value of $\arcsin \sqrt{\% \mathrm{G}}$. The estimated germination after 12 months of storage from this temperature-relative humidity combination was $99.9 \%$. Lower G occurred at all temperatures when relative humidity levels exceeded $39 \%$. The relative humidity level during seed storage was found to have a larger
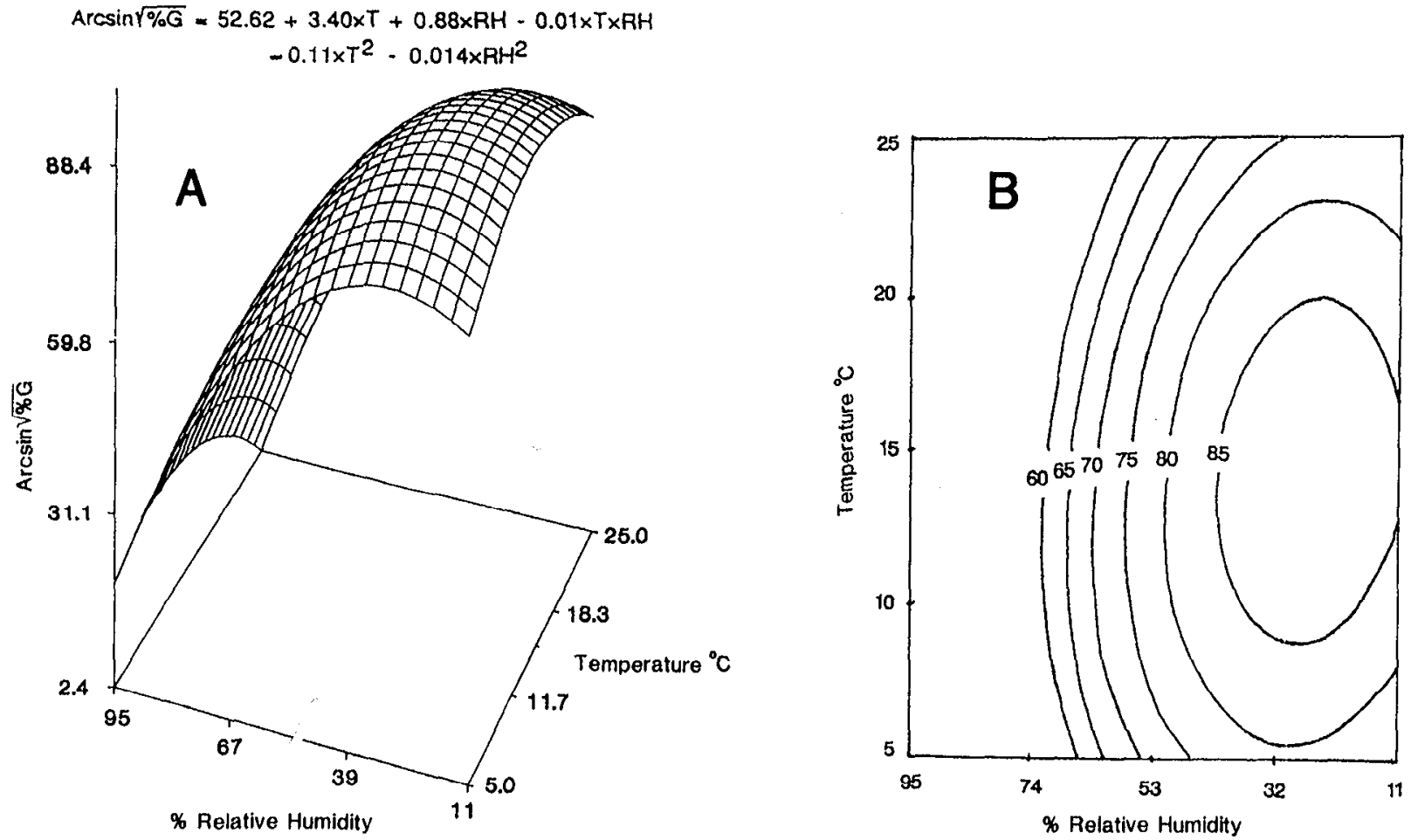

Fig. 5. Three-dimensional (A) and contour plots (B) using the arasin $\sqrt{\%}$ Germination to compare the relationship between relative humidity and temperature during 12 months of seed storage on germination. Contour lines (B) represent estimated percentages of total germination after seed storage. 

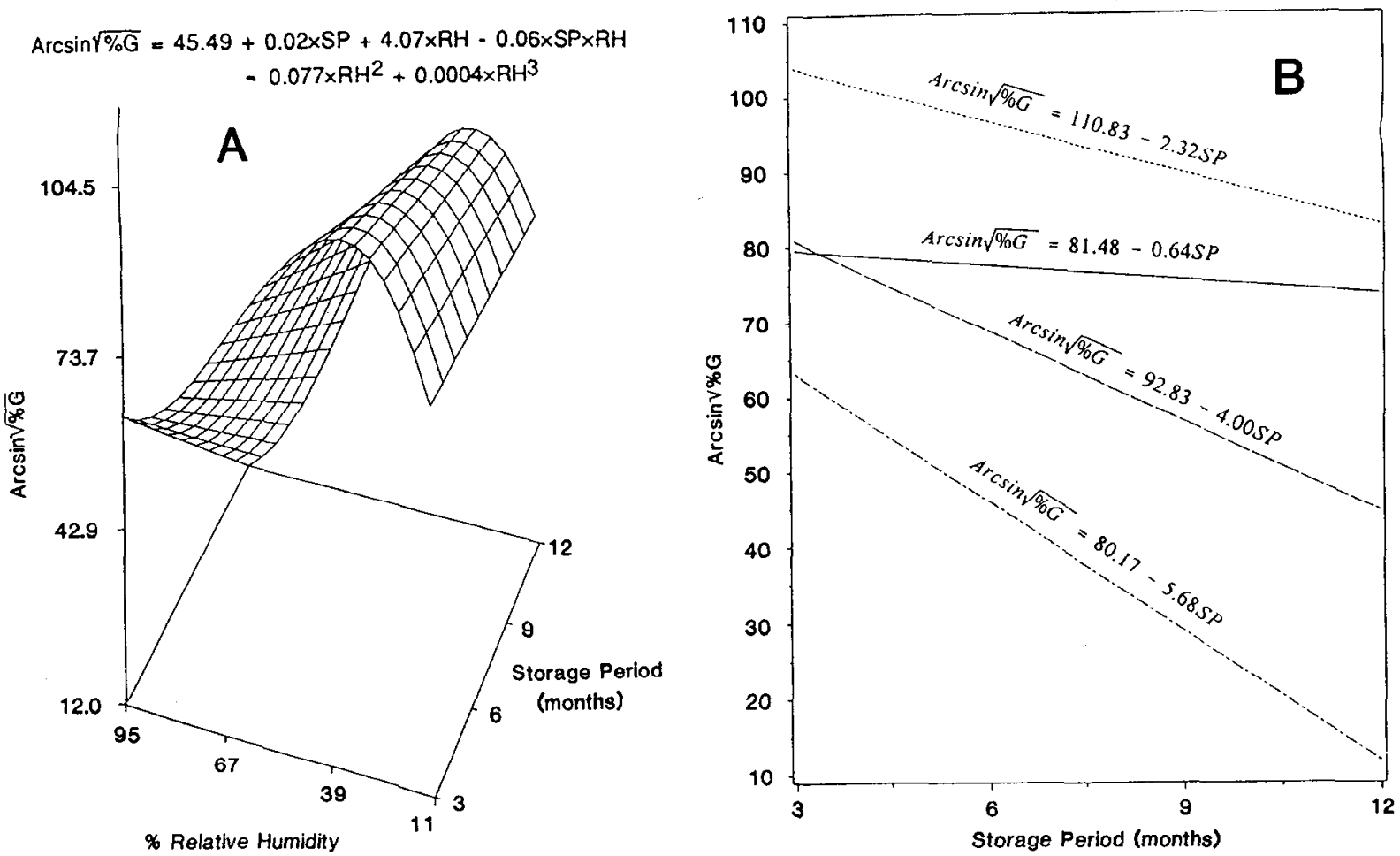

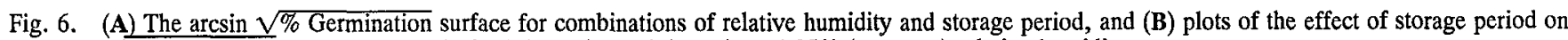

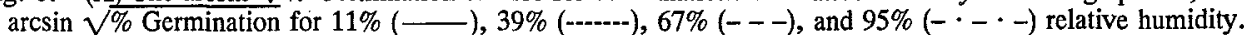

effect on $\mathrm{G}$ than storage temperature (Fig. 5B). Plots evaluating storage periods of 3 , 6,9 , or 12 months at different $\mathrm{RH}$ levels indicated that the least decline in $\mathrm{G}$ occurred during storage at $11 \%$ or $39 \% \mathrm{RH}$, with progressively larger declines at $67 \%$ and $95 \%$ RH (Fig. 6 A, B). Seeds dehydrated at 105C following 12 months of storage at $11 \%$ or $33 \% \mathrm{RH}$ were found to contain $8.1 \%$ and 9.6\% moisture contents, respectively, levels that did not reduce $G$ values or increase $T_{50}$ or $\mathrm{T}_{90}-\mathrm{T}_{10}$ in the dehydration study (Fig. 3).

These studies help us better understand the frequent low total and irregular germination of gladiolus seed and the rapid loss of viability during storage. The data reported should assist in developing recommendations for the improved germination, handling, and storage of gladiolus seeds. Breeders depend on seeds to gain access to native gladiolus species and need long-term seed storage for breeding lines. Our results demonstrate that gladiolus seed can be stored at $14 \mathrm{C}$ and $26 \%$ $\mathrm{RH}$ for 12 months with only a small loss in germination. Since gladiolus seed is tolerant of subfreezing temperatures, further lengthening of the seed storage period may be possible.

\section{Literature Cited}

Bewley, J.D. and M. Black. 1986. Seeds: physiology of development and germination. Plenum, New York.

Copeland, L.O. 1976. Principles of seed science and technology. Burgess, Minneapolis.

Emsweller, S.L. 1930. Some results of storing gladioli at various temperatures. Amer. Soc. Hort. Sci. Proc. 27:550-553.

Furutani, S.C., B.H. Zandstra, and H.C. Price. 1985. Low temperature germination of celery seeds for fluid drilling. J. Amer. Soc. Hort. Sci. 110:149-153.

Griesbach, R.A. 1972. The life-structure and function in gladiolus. The world of the gladiolus. Edgewood Press, Edgewood, Pa. p. 840
Guy, C.L. and J.V. Carter. 1984. Characterization of partially purified glutathione reductase from cold hardened and nonhardened spinach leaf tissue. Cryobiology 21:454-464.

Kelly, R.B. 1953. From seed to bulb. Gladiolus 28:929-132.

Lewis, G.J., A.A. Obermeyer, and T.T. Barnard. 1972. A revision of the South African species of gladiolus. J. S. Afr. Bot. Suppl. vol. 10.

Magie, R.O. and S.L. Poe. 1972. Disease and pest associates of bulb and plant. The world of the gladiolus. Edgewood Press, Edgewood, Pa. p. $155-181$.

Pickell, C. 1972. Growing bulblets and seed. The world of the gladiolus. Edgewood Press, Edgewood, Pa. p. 90-97.

Pridham, A.M.S. 1930. Do storage conditions influence the growth of the gladiolus? Gladiolus Rev. 7:278-282.

Pridham, A.M.S. and R.G. Thompson. 1930. A study of the gladiolus with reference to preseason bloom. Proc. Amer. Soc. Hort. Sci. 27:550 553.

SAS Institute. 1982. SAS user's guide: Statistics. SAS Institute, Inc., Cary, N.C. 